\title{
Alternative Forms of Judicial Review
}

Mark V. Tushnet

Georgetown University Law Center, tushnet@law.georgetown.edu

Reprinted from Michigan Law Review, August 2003, Vol. 101, No. 8. Copyright 2003 by Mark V. Tushnet.

This paper can be downloaded free of charge from:

https://scholarship.law.georgetown.edu/facpub/259

101 Mich. L. Rev. 2781-2802 (2003)

This open-access article is brought to you by the Georgetown Law Library. Posted with permission of the author. Follow this and additional works at: https://scholarship.law.georgetown.edu/facpub

Part of the Constitutional Law Commons, and the Jurisprudence Commons 


\title{
GEORGETOWN LAW Faculty Publications
}

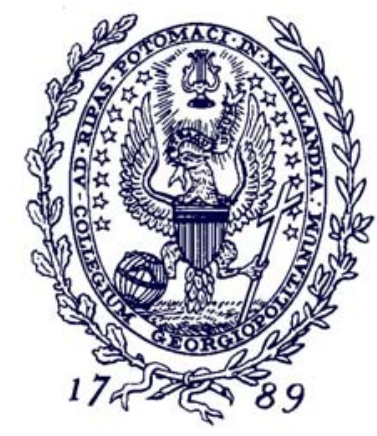

February 2010

\section{Alternative Forms of Judicial Review*}

101 Mich. L. Rev. 2781-2802 (2003)

\author{
Mark V. Tushnet \\ Professor of Law \\ Georgetown University Law Center \\ tushnet@law.georgetown.edu
}

This paper can be downloaded without charge from:

Scholarly Commons: http://scholarship.law.georgetown.edu/facpub/259/

Posted with permission of the author

* Reprinted from Michigan Law Review, August 2003, Vol. 101, No. 8. Copyright 2003 by Mark

V. Tushnet. 


\title{
ALTERNATIVE FORMS OF JUDICIAL REVIEW
}

\author{
Mark Tushnet*
}

The invention in the late twentieth century of what I call weak-form systems of judicial review provides us with the chance to see in a new light some traditional debates within U.S. constitutional law and theory, which are predicated on the fact that the United States has strong-form judicial review. ${ }^{1}$ Strong- and weak-form systems operate on the level of constitutional design, in the sense that their characteristics are specified in constitutional documents or in deep-rooted constitutional traditions. After sketching the differences between strong- and weak-form systems, I turn to design features that operate at the next lower level. Here legislatures or courts specify whether their enactments or decisions will receive strong- or weak-form treatment. I examine examples of legislative allocations of issues to strong- and weak-form review and identify some practical and conceptual problems with such allocations. Then I examine judicial allocations - of the courts' own decisions - to strong- or weak-form categories. Here I consider Thayerian judicial review and what Professor Dan Coenen has called semisubstantive doctrines as examples of judicial choices to give their decisions weak-form effects. ${ }^{2} \mathrm{My}$ conclusion is that these allocation strategies reproduce within strong- and weak-form systems the issues that arise on the level of constitutional design. Weak-form systems and allocation strategies

* Carmack Waterhouse Professor of Constitutional Law, Georgetown University Law Center. B.A. 1967, Harvard; J.D. 1971, M.A. (History) 1971, Yale. - Ed. This Essay is one of a series on modern forms of judicial review. Its specific focus arose from comments by Walter Sinnott-Armstrong on a draft of one of those essays, Forms of Judicial Review as Expressions of Constitutional Patriotism, 22 LAW \& PHIL. 353 (2003), and I am indebted to Professor Sinnott-Armstrong for turning my thought in this direction. I also profited from comments at a presentation at Seattle University Law School and by Barry Friedman, Jeff Goldsworthy, and Lorraine Weinrib.

1. For definitions of strong- and weak-form judicial review, see Section I.A infra. As the ensuing discussion indicates, the assertion that weak-form systems were invented in the late twentieth century may be overstated. Perhaps a more accurate statement would be that judicial review was invented in a weak form, but became transformed over two centuries to the point where weak-form systems had to be reinvented, with novel design features, in the late twentieth century.

2. Dan T. Coenen, A Constitution of Collaboration: Protecting Fundamental Values with Second-Look Rules of Interbranch Dialogue, 42 WM. \& MARY L. REV. 1575 (2001) [hereinafter Coenen, Constitution of Collaboration]; Dan T. Coenen, The Rehnquist Court, Structural Due Process, and Semisubstantive Constitutional Review, 75 S. CAL. L. REV. 1281 (2002) [hereinafter Coenen, The Rehnquist Court]. 
may seem to alleviate some difficulties associated with strong-form systems in constitutional democracies. My analysis suggests that those difficulties may persist even when alternatives to strong-form judicial review are adopted.

\section{STRONG- AND WEAK-FORM JUDICIAL REVIEW - SOME DISTINCTIONS}

\section{A. The Basic Distinction}

For perhaps a century the nature of judicial review in the United States was uncertain. Although Marbury v. Madison confirmed that the U.S. Supreme Court had the power to declare unconstitutional a statute enacted by Congress, the scope of the Marbury power, and its relation to the Constitution-interpreting roles of the other branches, remained contested for decades. Marbury can be taken to establish a system of what some scholars call a departmentalist system of judicial review.

Departmentalism comes in two variants. In the first, each department has sole responsibility for determining the constitutionality of actions by other departments affecting its own operation. ${ }^{3}$ Marbury is a departmentalist decision in this sense because the Court determined that Congress had improperly rearranged the Constitution's allocation of power within the judiciary. ${ }^{4}$ In the second variant of departmentalism, each branch has a constitutional right or perhaps even a duty - to act on its own best interpretation of the Constitution, no matter what the other branches have said..$^{5}$ Marbury is departmentalist in this sense too, because the Court rejected a reasonable interpretation of the Constitution, adopted by Congress and the president in enacting the Judiciary Act provision invalidated there, in favor of its own interpretation. ${ }^{6}$

3. The basic studies of departmentalism are ROBERT L. CLINTON, MARBURY $V$. MADISON AND JUdiCIAL REVIEW (1989), and SHANNON C. STIMSON, THE AMERICAN REVOLUTION IN THE LAW: ANGLO-AMERICAN JURISPRUDENCE BEFORE. JOHN MARSHALL (1990).

4. Most of the precedents for judicial review were departmentalist in this sense, involving, typically, statutes affecting the role of juries.

5. For an overview of this position, see Michael Stokes Paulsen, The Most Dangerous Branch: Executive Power to Say What the Law Is, 83 GEO. L.J. 217 (1994).

6 . In this version of departmentalism, the views of the other branches play two roles. First, those views are entitled to respectful consideration, as data bearing on each department's own interpretation, but they are not conclusive. Second, the fact that one department disagrees with another has implications for the prudential judgment about what ought to be done given the disagreement. Sometimes the costs to the constitutional system of a department insisting on its own interpretation, in terms of stability and the like, may be so large as to justify the department in refusing to act on its own judgment while insisting on its power to do so. 
Departmentalism in its first variant was a reasonable description of constitutional practice for much of the nineteenth century. Vigorous constitutional debates about the tariff, the scope of Congress's power to subsidize "internal improvements" such as roads that would link one part of the nation to another, and - of course - slavery took place in Congress and in presidential campaigns.' For example, Andrew Jackson vetoed the act rechartering the Bank of the United States, partly because he thought that, the Supreme Court notwithstanding, Congress lacked the power to charter a bank. The veto message stated: "The opinion of the judges has no more authority over Congress than the opinion of Congress has over the judges, and on that point the President is independent of both."

At some point this departmentalist practice weakened substantially. ${ }^{9}$ The people of the United States, acting through our institutions, had to define the contours of our system of judicial review because the Constitution says nothing about the institution. Judicial review changed from the means by which the courts expressed their view of the Constitution's meaning, in a system where other institutions expressed their own independent views, to a mechanism for lodging responsibility for constitutional interpretation in a single institution, the judiciary. ${ }^{10}$ So, for example, in 1935 Franklin Delano Roosevelt advised a member of Congress to put aside his constitutional doubts and "leav[e] to the courts, in an orderly fashion, the ultimate question of constitutionality."11 Cooper v. Aaron asserted that the Court's interpretations bind all political actors. ${ }^{12}$ And, though an assertion by the Court of its own power cannot make it so, Cooper has

7. For some examples, see H. JEFFERSON POWELL, A COMMUNITY BUILT ON WORDS: THE CONSTITUTION IN History AND POLITICS (2002); KEITH WhITTINGTON,

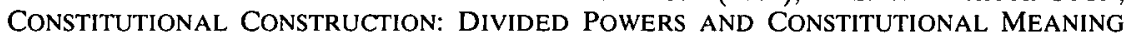
(1999); and Mark Graber, Resolving Political Questions into Judicial Questions: Tocqueville's Thesis Revisited, Paper Presented at the Annual Meeting of the American Political Science Association (2000) (on file with author). 1900).

8. 2 Messages ANd Papers of THE PREsidents 576, 581-82 (James Richardson ed.,

9. I am unaware of a definitive history identifying with any precision the period when departmentalism substantially disappeared. The possibilities range, I think, from the late nineteenth century to the middle of the twentieth.

10. Cooper v. Aaron, 358 U.S. 1 (1958), clearly assumes that the U.S. system is strong-form and, as I will argue, Thayerian judicial review does so as well. In light of the latter point, I suppose we can say that strong-form review existed - as a target for Thayer's analysis, at least - by the 1890 s.

11. Kathleen A. Sullivan \& Gerald Gunther, Constitutional Law 22 (14th ed. 2001). Roosevelt continued with words that can be given a slightly more departmentalist reading: "A decision by the Supreme Court relative to this measure would be helpful as indicating [the] constitutional limits within which this Government must operate." Id. (emphasis added). "Helpful as indicating" is more departmentalist than, for example, "would indicate" would have been.

12. 358 U.S. 1 (1958). 
been taken to be at most a slightly overstated formulation of the nondepartmentalism that characterizes contemporary judicial review in the United States. ${ }^{13}$

Strong-form judicial review rejects both forms of departmentalism. In strong-form judicial review, the courts have general authority to determine what the Constitution means. ${ }^{14}$ And, more important for present purposes, the courts' constitutional interpretations are authoritative and binding on the other branches, at least in the short to medium run. ${ }^{15}$

The strong-form aspect of the U.S. system became the model for the constitutional courts adopted by other nations after World War II, even as system-designers rejected other aspects of the U.S. system. ${ }^{16}$ For example, the German Constitutional Court, perhaps the world's leading constitutional court after the U.S. Supreme Court, is a strong-form court. ${ }^{17}$ And, for many years, it seemed that judicial review meant strong-form review, a fact that provided an argument against the institution for those concerned about giving a substantial policymaking role to (mere) judges. ${ }^{18}$

The possibilities for institutional design changed, however, when the drafters of Canada's Charter of Rights invented weak-form judi-

13. Citing additional Supreme Court cases such as Dickerson v. United States, 530 U.S. 428 (2000), and City of Boerne v. Flores, 521 U.S. 507 (1997), would not support this assertion, but perhaps citing the controversy over Attorney General Edwin Meese's assertion in a 1987 speech of a moderate departmentalist view will. For citations, see SULLIVAN \& GUNTHER, supra note 11 , at 25-26.

14. Whatever limits there are on that authority, such as those imposed by the political question doctrine or interpretive approaches counseling deference to the policy judgments of the other branches, originate from the courts themselves. For a discussion of the difference between deferential review and Thayerian review, see infra text accompanying notes 64-65.

15. Judicial interpretations are not absolutely binding, first, because they can be overturned by a constitutional amendment, which in principle could occur quite rapidly (as occurred with the Eleventh Amendment), and second, because they can be rejected as new justices are appointed to the Court and constitutional doctrine changes.

16. For example, system-designers seem to have believed that judicial independence could be secured without giving the judges life tenure, and that doing so promoted other important constitutional values. Some system-designers also apparently believed that systems of judicial review should incorporate as expressly as possible the judgment that constitutional review was a task that combined legal and political dimensions.

17. Although German legal theorists took some time to reconcile the practice of strong-form review with their jurisprudential assumptions. For brief discussions, see DAVID P. Currie, The Constitution of the Federal Republic of Germany 169 n.346 (1994), and DONAld P. KOMMERS, THE CONSTITUTIONAL JURISPRudenCE OF THE FEDERAL REPUBLIC OF GERMANY 54 (2d ed. 1997).

18. Often this concern is phrased as one about the diminution of a people's self-governing capacity when courts exercise strong-form review. Understood in that way, the concern is alleviated, if not eliminated, when the people knowingly acquiesce in strongform review. For a discussion, see Mark Tushnet, Forms of Judicial Review as Expressions of Constitutional Patriotism 22 LAW \& PHIL. 353 (2003). 
cial review in $1981 .{ }^{19}$ The Charter's now-famous Section 33 allows the legislature to determine that a statute would go into effect notwithstanding its possible conflict with specified Charter provisions. One point of the notwithstanding clause was to give the Canadian Supreme Court a role in constitutional interpretation without making that Court's judgments completely authoritative in the short run. A legislature that disagreed with the court's interpretation could reenact the legislation found invalid, protecting against a subsequent challenge by invoking Section $33 .^{20}$

Section 33 appears to have encouraged other system-designers to think creatively about the forms of judicial review. For present purposes I need mention only two, the New Zealand Bill of Rights and the British Human Rights Act of 1998. The former directs the courts to interpret all legislation so as to make the legislation compatible with the Bill of Rights, but gives the courts no power to refrain from enforcing statutes that, fairly read, are inconsistent with the Bill of Rights. ${ }^{21}$ The latter couples the interpretive directive with a judicial power to declare a statute incompatible with guaranteed rights and an ensuing ministerial power to modify the statute rapidly, to bring it into compliance with those rights. ${ }^{22}$

19. For a discussion of the circumstances under which the invention occurred, see Peter W. Hogg, Constitutional law of Canada (3d ed. 1992).

20. The story did not develop quite as the inventors imagined. For complex reasons one of which may have been the infelicity of drafting $\$ 33$ to refer to action notwithstanding the Charter's provisions rather than action notwithstanding a judicial interpretation of those provisions - $\$ 33$ has, I believe, turned out to be something of a nonprovision in Canadian constitutional law. The fact that $\$ 33$ can be used prior to a judicial interpretation, thereby protecting against even an initial judicial interpretation, probably makes sense, but both in theory and in practice such prospective uses create problems. The terms of a provision authorizing prospective uses would have to be quite complex to capture the idea that a prospective use was guarding against a Supreme Court misinterpretation of the Charter. The actual prospective uses, by Québec as part of its struggle for independence and by Alberta to protect against an anticipated Supreme Court holding that laws barring gays from marrying violate equality norms, have not given the prospective use of $\$ 33$ a good name in Canadian constitutional culture. For a discussion, see Mark Tushnet, New Forms of Judicial Review and the Persistence of Rights- and Democracy-Based Worries, 38 WAKE FOREST L. REV. 813 ( 2003) [hereinafter Tushnet, New Forms of Judicial Review].

My view of $\S 33$, I should note, while not idiosyncratic, is one that is quite controversial among Canadian constitutionalists (when asserted by Canadian scholars who have studied the system more than I have). Those who assert that $\$ 33$ has operated well, and as intended, note that it was not designed with frequent use in mind, and that its existence has had an effect on structuring statutory design, so that rare recourse to $\$ 33$ does not show that the provision has been ineffective.

21. The Canadian Charter of Rights displaced an earlier Canadian Bill of Rights, which provided the model for the New Zealand Bill of Rights.

22. See Stephen Gardbaum, The New Commonwealth Model of Constitutionalism, 49 AM. J. COMP. L. 707 (2001), for a discussion of these forms of judicial review. I prefer the label weak-form to "Commonwealth model," because I do not think that there is any intrinsic connection between the form of judicial review and the fact that the best examples come from the Commonwealth. Weak-form systems are a natural response to a desire to impose judicially enforceable limits on legislative action in nations where the tradition of parliamen- 
The mark of weak-form review is not that the scope of judicial review is narrow. Courts in weak-form systems have the power to evaluate all legislation to determine whether it is consistent with all of the constitution's provisions without exception. Rather, the mark of weak-form review is that ordinary legislative majorities can displace judicial interpretations of the constitution in the relatively short run. ${ }^{23}$ Weak-form review responds to the concern that strong-form review allows courts with an attenuated democratic pedigree to displace decisions taken by bodies with stronger democratic pedigrees. Yet, weakform systems raise their own concerns - primarily, that weak-form review, to use Marbury's terms, converts the Constitution into an "ordinary legislative act[] ... alterable when the legislature shall please to alter it." 24

Strong-form and weak-form judicial review are ways of structuring judicial review. Scholars of constitutional structure have given insufficient attention, I believe, to the question of who selects the form of review. The remainder of this Article addresses that question.

\section{B. The Level of Institutional Choice}

As presented so far, the choice between strong- and weak-form judicial review seems to occur at the most fundamental level of institutional design. Sometimes the choice is made by the constitution's designers and is memorialized in the constitution; sometimes a nation's legal culture gradually accepts the proposition that judicial review takes a strong or a weak form. ${ }^{25}$ But, once we see that there is more than one form of judicial review, we can consider whether strong- and weak-forms can be created at the next level of institutional operation - not by the constitution's designers themselves, but by the legislators and judges who implement the constitution. ${ }^{26}$ The idea here

tary sovereignty is strong and has continuing support among politically relevant actors. Commonwealth nations may provide the best examples of such governments, but they are not the only ones.

23. Weak-form review thus rejects the first variant of departmentalism while embracing the second.

24. Marbury v. Madison, 5 U.S. (1 Cranch) 137, 177 (1803). This statement is inaccurate with respect to weak-form systems that place some procedural impediments in the way of easy legislative response, but each such impediment moves the purportedly weak-form system some way down the line toward strong-form systems.

25. The United States exemplifies the first of these gradualist paths. Perhaps Sweden exemplifies the second. The Swedish Constitution of 1915 created a constitutional court with the power of judicial review, but that court did not find primary legislation unconstitutional for more than seven decades. A culture of weak-form review may be one explanation, but so may be the language of the Swedish Constitution, which enjoins the court to "set aside" a statute "only if the fault is manifest." Swed. Const., Ch. 11, art. 14, available at http://www.uni-wuerzburg.de/law/sw00000_html (last visited Nov. 8, 2003).

26. Walter Sinnott-Armstrong characterized these forms of judicial review as intermediate between strong- and weak-form. As indicated in the text, I believe it is better to concep- 
is that legislators and judges can allocate particular issues or statutes to strong- or weak-form judicial review, while leaving other issues to a default form of review. ${ }^{27}$

There are, however, asymmetries in the choices available in strong- and weak-form systems. Legislators in a system of weak-form review on the constitutional level can require courts to exercise strong-form review, thereby relinquishing their own power to revisit the issues they remit to the courts. ${ }^{28}$ But, the courts in a weak-form system cannot themselves choose to exercise strong-form review. ${ }^{29}$ And, in parallel fashion, courts where the default position established by the constitution is strong-form review can decide for themselves to allow legislatures to "override" the courts' decisions on some matters, by issuing decisions that, through a variety of doctrinal devices, are by their own terms merely provisional ${ }^{30}$ But, legislatures in a strong-form system cannot require that courts make their decisions on some questions readily revisable.

These asymmetries complicate the exposition of designs that allow for choice between strong- and weak-form review at the legislative and judicial levels. Although my primary concern is with constitutional design in general, my primary strategy for addressing this difficulty is to draw examples from periods when it remained unsettled whether the U.S. system was strong- or weak-form. ${ }^{31}$ In doing so, I do not mean

tualize them as dealing with the creation of judicial review at a different level than the constitution. For me, an intermediate form of review would be one that adopted something like a moderately strong form of departmentalism coupled with a moderately strong form of judicial exclusivity. I do not know how such a system could be designed, and, in general, I am skeptical of the stability of anything other than truly strong-form systems or truly weak-form ones. For a discussion of the possible instability of Canada's purportedly weak-form system, see Tushnet, New Forms of Judicial Review, supra note 20.

27. Or, at least in theory, to a default of no review at all. In the modern world, however, designers of constitutional systems have universally chosen to insert judicial review into their designs.

28. Subject to an important qualification discussed in Part II of this Essay.

29. Except, of course, as a move in a long-term process through which weak-form review is converted into strong-form review.

30. A note on Dormant Commerce Clause review in the United States is appropriate here. The Supreme Court has held that its determinations that state regulations "unconstitutionally" interfere with interstate commerce can be revised by Congress, through statutes that give states permission to enact the laws the Court invalidated. See, e.g., In re Rahrer, 140 U.S. 545 (1891). For a discussion, see William Cohen, Congressional Power to Validate Unconstitutional State Laws: A Forgotten Solution to an Old Enigma, 35 STAN. L. REV. 387 (1983). One can view this doctrine as a choice by a strong-form Court to engage in weak-form review. Alternatively, one can view it as a doctrine that does not involve judicial review at all, seeing the courts as agencies exercising a power Congress delegated to them that is subject to ordinary congressional review and oversight.

31. Or, at least, I invite readers to consider the examples on the assumption that the choice remained open at the constitutional level. (Of course I also provide examples from situations where the asymmetries do not matter.) 
to suggest that all the possibilities I discuss are available now that the U.S. system has become a strong-form one.

\section{Allocation BY THE LEgISLATURE}

Mark Graber's analysis of Dred Scot ${ }^{32}$ and the abortion cases ${ }^{33}$ illustrates the strategy of legislative allocation. ${ }^{34}$ According to Graber, legislative majorities in those instances invited the courts to resolve a constitutional controversy. In the 1850s, the Northern and Southern wings of the congressional Democratic Party - together, a working majority in Congress - found it impossible to resolve their differences on the issue of whether Congress had the power to ban or regulate slavery in the territories. The party's leaders solved their problem by inviting the Supreme Court to decide the question, supporting the Dred Scott litigation in the lower courts and signaling the justices that the party leaders would welcome the Court's intervention. They would then defer to the Court, invoking the idea of strong-form review to justify their refusal to do anything other than go along with the Court.

Graber also suggests that, less consciously, deferring the abortion issue to the courts solved problems within both the Republican and Democratic party coalitions. ${ }^{35}$ Republicans were divided between an older, northeastern wing and an emerging southern and western wing that was more conservative on social issues than the Rockefeller Republicans of the northeast. Democrats were divided between a Catholic working-class constituency and limousine liberals. The abortion issue divided both party coalitions. Sending the issue to the courts allowed party leaders to avoid taking a position on legislation in a setting where taking any position would be politically damaging. And, notably, once the courts acted in a legal culture accepting strong-form review, the internal divisions became much less pressing: In each party, critics of the Court could have their say without forcing their coalition partners to do anything, because in a strong-form system there was nothing that could be done in the short run to respond to the Court.

Neil Devins has identified another contemporary version of this phenomenon. Devins notes the numerous statutory provisions providing for rapid Supreme Court review of constitutionally conten-

32. Dred Scott v. Sandford, 60 U.S. (19 How.) 393 (1856).

33. Roe v. Wade, 410 U.S. 113 (1973).

34. Mark A. Graber, The Nonmajoritarian Difficulty: Legislative Deference to the Judiciary, 7 STUD. AM. POL. DEV. 35 (1993).

35. I emphasize that, while there is evidence that party leaders consciously sought Supreme Court resolution of the slavery issue, there is no such evidence - nor does Graber claim there is - that party leaders were similarly conscious about deferring the abortion issue to the courts. 
tious legislation such as the Line Item Veto Act and campaign finance reform. ${ }^{36}$ In some formal sense perhaps, Congress takes the position that its enactments conform to the Constitution. But, the fast-track judicial review provisions also indicate uncertainty within Congress (that is, by enough members of Congress to make inclusion of a fasttrack review provision a politically sensible thing to do) about the correctness of its position. And, finally, these provisions indicate Congress's willingness to accept the Court as the final arbiter of the constitutional questions. It would be churlish indeed for Congress, having invited the Supreme Court to decide the constitutional question, to assert in departmentalist terms that the Court's views are interesting and relevant but not binding.

Yet, this sort of statutory charge to the Court to exercise strong-form review raises its own questions. Of course, the very Congress that invited the Court to decide is unlikely to rise up in outrage at what the Court does. But, the Dred Scott and abortion examples suggest that a perspective that has a slightly longer time horizon might give a different answer to the question of whether legislators will accept the Court's decisions and, thus, whether the Court actually can exercise strong-form review. The Dred Scott decision rapidly became a central issue of political contention, as the new Republican party exploited the decision to exacerbate tensions within the constituencies supporting the Democratic party. Dred Scott was decided in 1857. Less than a year later, the decision was a central feature in Abraham Lincoln's campaign against Stephen A. Douglas for a Senate seat to represent Illinois in Congress, a campaign that pushed Lincoln into the national spotlight. The national majority that elected Lincoln in 1860 repudiated Dred Scott politically. ${ }^{37}$ The Dred Scott story shows that a legislative allocation of a constitutional question to a nominally strong-form system may not achieve the intended goal. ${ }^{38}$

One can generalize a bit from the Dred Scott story. Legislative allocations to strong-form review can succeed as long as legislators and, importantly, those elected to succeed the initial enactors accept, not just the Supreme Court's decision, but also the initial deci-

36. Neil Devins, Congress as Culprit: How Lawmakers Spurred on the Court's Anti-Congress Crusade, 51 DuKE L.J. 435 (2001).

37. And, formally, Dred Scott was repudiated by the first sentence of the Fourteenth Amendment, adopted after the Civil War in 1868. See U.S. ConST. amend. XIV, \& 1 ("All persons born or naturalized in the United States, and subject to the jurisdiction thereof, are citizens of the United States and of the state wherein they reside.").

38. The abortion story is somewhat more complicated, involving as it does the quite gradual erosion of the position of northeastern Republicans within that party, coupled with the nomination and confirmation of federal judges hostile to the Supreme Court's abortion decisions. While the Dred Scott story indicates how a legislative allocation to a strong-form system may fail, the abortion story suggests that the legislative allocation can succeed because strong-form systems are defined by the power of courts to make their decisions stick in the medium to long run, as the abortion decisions have. 
sion to defer the issue to the courts. The issue purportedly taken off the table by the first legislature will reappear if members of the second legislature want it to. ${ }^{39}$

The reason arises from the asymmetry discussed earlier. A legislature can allocate issues to strong-form review only if the system is weak-form on the constitutional level. I use a stylized version of the events surrounding Ex parte McCardle to illustrate the point. ${ }^{40}$ After the Civil War, Congress engaged in a program of military occupation of the formerly rebellious states. The program's constitutionality was open to serious question. Congress enacted a statute expanding the scope of habeas corpus as part of the Reconstruction effort. One incidental consequence of that statute, whose implications were probably not foreseen, was an expansion of the scope of the Supreme Court's authority to review lower court decisions in habeas corpus cases. We can describe this as Congress inviting the Supreme Court to determine the Reconstruction program's constitutionality. An opponent of Congress's Reconstruction program took up the invitation and brought a habeas corpus petition to the Supreme Court using the new statute's procedures. Fearful that the Supreme Court might strike down the Reconstruction program, Congress then repealed the provision expanding Supreme Court review. Having put the constitutional question on the Court's agenda, in a manner akin to the one Graber describes, Congress then took it off the agenda.

Ex parte McCardle asked whether Congress could actually do that. That is, the issue in McCardle was whether one Congress could foreclose another Congress from withdrawing the invitation to the Court to decide the constitutional question. The Supreme Court said no; the initial decision by Congress could not bar a later one from taking jurisdiction away from the Court. Interpreting the Constitution's provisions dealing with Congress's power to regulate the Supreme Court's jurisdiction, the Court held that Congress's power was plenary, and that it was "not at liberty to inquire into the motives of the legislature." ${ }^{\prime 1} \mathrm{McC}$ Cardle, seen in the light cast by my argument, is a case in which the legislature in a system with weak-form judicial review invited the Supreme Court to exercise strong-form review, and then revoked the invitation, reinstituting the default system.

The $M c$ Cardle Court went along with Congress's decision. It might (in theory at least) have refused to do so. Such a decision would have been an assertion that power - here, the power to exercise

39. In effect, the later legislature says to the earlier one, "You're no longer around and can't do anything to bind us to the decision you made."

40. 74 U.S. (7 Wall.) 506 (1869). Stylization helps because the events as they actually unfolded are not precisely what is needed to make the point discussed in the text.

41. Id. at 514 . 
strong-form review - once delegated cannot be retrieved: The earlier legislature's decision does bind the later one by means of judicial enforcement of the earlier one's choice. But, does this make conceptual sense? After all, there is a long standing maxim of constitutional and statutory law, lex posterior derogat legi priori, meaning that "later law overrules earlier law." Why should not this maxim apply to the second legislature's revocation of the first legislature's allocation of an issue to strong-form review?

We can see why it is indeed applicable by considering why the maxim does not apply when a statute is challenged as inconsistent with an earlier adopted constitution. In some sense, all constitutions involve an irretrievable delegation of power. ${ }^{42}$ The people create a constitution that imposes restrictions on the people later on, as they act through their elected representatives. So, if constitutionalism is a form of irretrievable delegation, why could not the legislative authorization of strong-form review in a system whose constitution specifies weak-form review be similarly irretrievable?

European constitutional theory provides the answer..$^{43}$ That theory distinguishes between the people acting in their capacity to create a constitution, and the people acting within the framework of the constitution they have created. It describes the former as the pouvoir constituant - the constituting power - and the latter as the pouvoir constitueé - the constituted power. The pouvoir constituee is subordinate to the pouvoir constituant, so, while the constituting power can do whatever it wants, constituted powers may not. The real bite of the distinction comes in thinking through its institutional implications. European constitutional theorists tend to insist that different institutions must exercise the two powers. A constitutional convention can constitute power, but a legislature cannot. More generally, according to these theorists, action on the level of the pouvoir constituant can bind actors on the subordinate level, but, they say, an actor cannot bind future actors on the same level: A new constitutional convention can completely displace what a prior constitutional convention did, and a later legislature can completely repudiate what a prior one did. ${ }^{44}$

Seen in this light, and putting the specifics of the U.S. Constitution aside, the stylized version of $M c C$ ardle shows why a legislative strategy of allocating issues to strong-form review in a system of weak-form review on the level of constitutional design may be unstable. Political

42. As before, irretrievable must be understood here to mean "irretrievable without going through some extraordinary procedures."

43. For an introduction to this aspect of European constitutional theory, see Andrew Arato, Forms of Constitution and Making Theories of Democracy, 17 CARDOZO L. REV. 191 (1995).

44. Unless, of course, the constitution itself limits what later legislatures can do, for example through ex post facto clauses. 
circumstances arising in the short run might lead to new legislation revoking the allocation. And, because the distinction between weakand strong-form review depends entirely on whether judicial decisions can be displaced by political ones in the short run or only in the long run, this means that the strategy of legislative allocation is not, in principle, distinct from weak-form judicial review created at the constitutional level.

\section{Allocation By THE COURTS}

A court in a strong-form system may decline to exercise the power it has, not simply by exercising whatever discretion it may have to select cases or by invoking justiciability doctrines of its own making ${ }^{45}$ but also by casting its decisions in expressly provisional terms or by upholding legislation after applying a standard of review generous to the legislature. In the first mode, the court may hold that the action at issue might be permissible if taken by one body, such as the executive, but is not permissible when taken by another. Or, it may hold that the legislature has the power to accomplish its apparent goals, but only in a statute that states those goals more clearly than the one before the court. In the second mode, the court may find the legislation in some tension with constitutional norms, but not so obviously unconstitutional as to justify the court's displacing the legislature's choice.

Both modes of decision may be seen as choices by the courts to exercise weak-form review. Yet, one can question the efficacy of such choices. Exercises of provisional review may degenerate into - or may be disguises for - strong-form review, in situations where the cost to the legislature of revisiting the issue is greater than the benefit of doing so. This is normatively troubling when there is some social gain from the initial legislation. The theory of provisional review is that the legislature can do better for the society by a more carefully drafted statute, for example. But, if no alternative statute could be enacted for practical political reasons, society loses the benefit of the badly drafted statute, without the court taking responsibility for limiting society's choices in the name of the constitution, as it does when it openly exercises strong-form review.

The difficulty with deferential review is subtler. The kind of deferential review with which I am concerned occurs when the court acknowledges that its understanding of the constitution leads it to conclude that the statute is inconsistent with constitutional norms, but defers to the legislature's understanding, which it treats as reasonable albeit erroneous. The question about this kind of deferential review is: 
What does it accomplish in a system committed to strong-form review?

\section{A. Judicial Choices to Make Review Provisional}

Courts with the power to make conclusive decisions need not exercise that power, though they may have a duty to decide in favor of one or the other litigant. They may exercise provisional rather than conclusive review - suspending the effect of a statute pending its reconsideration by the legislature, while holding out the promise that the legislation, or something quite like it, will be allowed to go into effect the next time around. Dan Coenen has recently compiled a catalogue of devices for provisional review, and carefully analyzed each. ${ }^{46}$ Rather than repeat his survey in detail, I provide a few examples as the basis for a discussion of two points: the extent to which provisional review is truly provisional, and the extent to which the devices of provisional review can be used by courts in allocating issues to weak-form review.

Justice Hans Linde and the Supreme Court introduced the idea of provisional review to modern U.S. constitutional law in 1976. Justice Linde's article Due Process of Lawmaking argued that the way in which laws were enacted and by whom should affect the courts' later assessment of their constitutionality, independent of the statutes' substance. ${ }^{47}$ Using this rationale, in Hampton v. Mow Sun Wong the Supreme Court held unconstitutional a regulation adopted by the Civil Service Commission that barred resident aliens from civil service positions. ${ }^{48}$ The Court agreed that such a ban might serve valuable foreign-policy goals, but concluded that the Civil Service Commission lacked the expertise - and the power - to promote U.S. foreign policy in this way. Professor Coenen describes Hampton as a case holding that the Constitution prescribes who must make particular decisions without limiting the substance of those decisions once made by the proper body. ${ }^{49}$ It exemplifies weak-form judicial review as well, because no special procedures other than ones within the control of an ordinary legislature need be followed - no supermajorities, no extended consideration, nothing beyond a process that could have been used in enacting the statute in the first place.

Professor Coenen elaborates a large number of similar rules, which he describes as "how" rules - ones that tell legislatures how to go about accomplishing the goals they seek in a constitutionally permissi-

46. Coenen, Constitution of Collaboration, supra note 2; Coenen, The Rehnquist Court, supra note 2.

47. 55 NEB. L. REV. 197 (1976).

48. 426 U.S. 88 (1976).

49. Coenen, The Rehnquist Court, supra note 2, at 1370-74 (describing other "who" decisions as well). 
ble way. The most obvious examples are clear-statement rules, which in terms say explicitly that the Constitution does not preclude the legislature from a particular goal but does require that the legislature specify with some care exactly what it proposes to do. ${ }^{50}$ Professor Coenen points out that rules sometimes criticized as exalting form over substance have the same "how" structure. ${ }^{51}$ He uses the example of the Court's Dormant Commerce Clause cases. There the Court has expressly said that discriminatory taxes can have the same adverse effects on interstate commerce that discriminatory subsidies do, but that discriminatory subsidies are permissible and discriminatory taxes prohibited. $^{52}$

In all of these areas, and many others, the Supreme Court says, in effect:

You can do what you seem to want to do, but you haven't gone about it in the right way. If you really care about this, go back and try again. If you follow our directions about who has to make the decision, and how it must be expressed, we'll uphold it against a renewed challenge.

So, for example, after Hampton the president repromulgated the ban on aliens in the civil service, and the courts upheld the renewed ban because the president was the right person to make foreign-policy decisions. ${ }^{53}$ Notably, the repromulgation occurred within a very short period after the Supreme Court's initial decision, thus demonstrating in concrete terms how the case exemplifies weak-form judicial review.

Yet, one can raise some questions about whether these devices are generally versions of weak-form review or rather disguised forms of strong-form review. The concern is that the devices hold out the hope of reenactment followed by unsuccessful constitutional challenge, but may be used in circumstances where practical politics make reenactment extremely unlikely.

The tax-subsidy cases provide a useful starting point. The theory behind the cases is that express subsidies will attract more political attention within the enacting state, because they involve appropriations, and therefore will be more difficult to enact than discriminatory taxes will be. That is to say, though, that the courts know that taxes and subsidies are economically equivalent devices but are politically different. Striking down a discriminatory tax while saying that a

50. Vagueness cases are similar, in that they involve judicial determinations, not that a legislature cannot accomplish a particular goal, but that the statute the legislature has adopted does not identify clearly enough that it aimed only at that goal rather than at other ends fairly encompassed by the statute's language as well.

51. Coenen, The Rehnquist Court, supra note 2, at 1329-35.

52. West Lynn Creamery, Inc. v. Healy, 512 U.S. 186 (1994); see also Coenen, The Rehnquist Court, supra note 2, at 1329 (citing cases and commentary).

53. Mow Sun Wong v. Campbell, 626 F.2d 739 (9th Cir. 1980), cert. denied sub nom., Lum v. Campbell, 450 U.S. 959 (1981). 
discriminatory subsidy if enacted will be upheld is, in practical political terms, an exercise of strong-form review because the courts know or believe, with good reason - that no discriminatory subsidy will in fact be adopted.

The point about the politics of enacting judicially acceptable alternatives can be generalized. The best defense of provisional review is that it allows the courts to bring to the legislature's attention constitutional values that it may have overlooked or given less value than the courts think it should have. After a provisional invalidation, the legislature can take the overlooked value into account or place a new weight on the value and enact a new, somewhat modified statute, or decide that, all in all, it had placed the correct weight on the value in its initial enactment. Provisional review means that the courts should uphold the new, modified statute or the old reenacted one. The difficulty with this defense of provisional review is that it overestimates the ease with which a legislature can revisit its earlier decisions. ${ }^{54}$

Enacted statutes embody a set of political choices and compromises among the members voting for the statutes. Change a statute's terms by requiring greater precision or a clearer statement, and you change the array of political forces. Someone who might support a statute that only indirectly imposes costs on states, for example, might be unwilling to support a statute that directly did so. Requiring a clear statement in such a situation means, in practical effect, barring Congress from imposing the costs at all. Even more generally, "who" and "how" requirements increase the cost of legislating (beyond the cost that exists in the absence of such requirements). Increase the cost, and you diminish the supply. The mechanism is simple: Legislators have a lot of things to do, and the more costly you make doing one of them, the more readily they switch to doing something else. ${ }^{55}$

Seemingly provisional review, then, may not be provisional in practice. ${ }^{56}$ In addition, and perhaps more important in the present context, it is not clear that forms of provisional review provide a strategy that courts can use to allocate some issues to strong-form review and others to weak-form review. In introducing his analysis, Professor Coenen asserts that "the Court confines its use of semisubstantive rulings to cases in which the substantive values at stake are (in the Court's view) distinctively deserving of judicial protection." ${ }^{27}$ As the

54. The quick readoption of the regulation at issue in Hampton shows that the difficulties I have identified are not insurmountable. Notably, though, readopting the regulation required only action by the president, not new legislation. I note that even presidential action may face impediments as proposals are processed through the executive bureaucracy.

55. For a brief elaboration of this point, see Mark Tushnet, Judicial Activism or Restraint in a Section 33 World, 53 U. TORONTO L.J. 89 (2003).

56. For a general discussion, see Tushnet, New Forms of Judicial Review, supra note 20, at $\S$ IV.

57. Coenen, The Rehnquist Court, supra note 2, at 1283. 
examples accumulate, though, that assertion seems increasingly questionable. Professor Coenen shows that the Court uses these devices in virtually every area of constitutional law. His later observation, that the Court's use of the doctrines is "widespread," seems more accurate. ${ }^{58}$ Professor Coenen connects his argument to Professor Cass Sunstein's defense of judicial minimalism, which has been taken as an account of what the courts should do across-the-board. ${ }^{59}$ To the extent that Professor Coenen's account describes contemporary U.S. practice, the Court does not appear to be using the devices as part of an allocation strategy.

And, perhaps, for good reason. Recall Professor Coenen's formulation, that the Court uses provisional review when "the substantive values" are "distinctively deserving of judicial protection." ${ }^{60}$ But, of course, those substantive values are values embodied in the Constitution. An allocation strategy predicated on Professor Coenen's formulation would lead the courts to sort values embodied in the Constitution into two boxes, one containing those "distinctively deserving" judicial protection, and the other, it would seem, containing those deserving judicial protection (given the existence of judicial review at all), but not distinctively so. ${ }^{61}$ Yet, the basis upon which constitutional values can be sorted is obscure, or at least is in some tension with the underlying theory of strong-form judicial review, which calls upon the courts to enforce the constitution as a whole. ${ }^{62}$

The devices Professor Coenen analyzes could form the basis for a strategy whereby the courts allocate some issues to weak-form review

58. Id. at 1396 .

59. Id. at 1397-98. Sunstein's own presentation is more qualified. He argues that maximalist decisions are appropriate when a number of conditions are met. Still, I believe Coenen is correct in using Sunstein's work in support of a general approach to constitutional adjudication, because that is how it has been assimilated into contemporary scholarship.

60. Id. at 1283 .

61. I simply note that, to the extent that we might think that some constitutional values are simply more important than others (along the lines of thinking that the First Amendment, for example, is more important than the Statement and Accounts Clause), we might think that weak-form or provisional review should be used for the less important values, and strong-form review for the more important ones. Alternatively, we might think that public attention will focus less on statutes implicating the less important values, thereby allowing Congress to reenact statutes provisionally invalidated without additional deliberation, with the implication that strong-form review should be used in connection with the less important values, and provisional review in connection with the more important ones. What is at stake in this note are the details of an allocation system, and I am more concerned with the very possibility of devising such a system than with its details.

62. Subject only to a minor exclusion of provisions that present political questions, an exclusion that is itself difficult to justify within a theory of strong-form judicial review. For discussions, see Louis Henkin, Is There a "Political Question" Doctrine?, 85 YALE L.J. 597 (1976), and Mark Tushnet, Law and Prudence in the Law of Justiciability: The Transformation and Disappearance of the Political Question Doctrine, 80 N.C. L. REV. 1203 (2002). 
and others to strong-form review. Yet, the practice he examines does not provide much assurance that such a strategy can sensibly be devised.

\section{B. Thayerian or Tutelary Review}

James Bradley Thayer's classic article on constitutional law defended the view that the Supreme Court should invalidate legislation only when the legislation was manifestly inconsistent with the Constitution. ${ }^{63}$ It is important to stress that Thayerian review is predicated on the assumption that the legislature has indeed made a constitutional error (in the court's eyes), in enacting a statute from whose enactment we infer that the legislature believed the statute to be constitutional. But, according to Thayer, the court should not set aside the legislature's erroneous judgment about what the constitution permits unless that judgment was quite seriously wrong.

True Thayerian review should be distinguished from the far more prevalent modern version of deferential review in, as the Supreme Court has put it, cases involving social and economic rights. ${ }^{64}$ In upholding a Maryland statute dealing with public assistance to the poor and distinguishing between such cases and those involving fundamental rights, the Court expressed its view that, by invoking a deferential standard of review, "We do not decide today that the Maryland regulation is wise, that it best fulfills the relevant social and economic objectives that Maryland might ideally espouse, or that a more just and humane system could not be devised." ${ }^{.65}$ Similarly, in sounding a "cautionary" note about the Court's decision upholding Texas's system of financing education primarily through the property tax, the Court asserted, "We hardly need add that this Court's action today is not to be viewed as placing its judicial imprimatur on the status quo. The need is apparent for reform in tax systems which may well have relied too long and too heavily on the local property tax." These are claims that the statutes in question may be unwise, rather than claims that the statutes are unconstitutional yet nonetheless will be accepted by the Court.

63. James Bradley Thayer, The Origin and Scope of the American Doctrine of Constitutional Law, 7 HARV. L. REv. 129 (1893). Thayer's formulation was, "It [the court] can only disregard the Act when those who have the right to make laws have not merely made a mistake, but have made a very clear one - so clear that it is not open to rational question." Id. at 144.

64. The canonical formulation is from Dandridge v. Williams, 397 U.S. 471, 485 (1970) ("In the area of economics and social welfare, a State does not violate the Equal Protection Clause merely because the classifications made by its laws are imperfect.").

65. Id. at 487.

66. San Antonio Indep. Sch. Dist. v. Rodriguez, 411 U.S. 1, 58 (1973). 
True Thayerian review involves statutes that the court believes to be unconstitutional according to the judges' independent assessment of the constitution, but which the court nonetheless refrains from striking down. It is hard to discover opinions endorsing truly Thayerian review. In recent years, the only such opinion of which I am aware is Justice Souter's opinion concurring in the judgment in Nixon $v$. United States. ${ }^{67}$ The case involved a challenge to the constitutionality of the Senate's procedure for trying impeachments initially before a committee and then on a paper review by the Senate as a whole. Justice Souter did not find those procedures unconstitutional, but, he wrote, he could "envision different and unusual circumstances that might justify a more searching review of impeachment proceedings." 68 These were circumstances in which "the Senate's action might be so far beyond the scope of its constitutional authority" that the courts should step in. ${ }^{69}$ Justice Souter's formulation implies that the courts might refrain from intervening when the Senate acted beyond its constitutional authority, but not "so far beyond" that authority as to warrant judicial intervention. ${ }^{70}$ This is indeed Thayerian review. ${ }^{71}$

Why do judges who understand the idea of deference in selected areas nonetheless rarely act as true Thayerians? There are, I believe, several reasons. First, note that Thayer presented his position as a general one, applicable to all constitutional provisions across the

67. 506 U.S. 224 (1993).

68. Id. at 253.

69. Id. at 254 (emphasis added).

70. Justice Souter's formulation resonates with my own understanding of Thayerian review. An alternative understanding treats Thayerian review as imposing an epistemic requirement on a judge's determination that a statute is unconstitutional. $A$ judge finding a statute unconstitutional must, on this understanding, conclude not simply that the statute is unconstitutional (based on a full analysis of all the relevant considerations), but that this conclusion is clear to a high degree of certainty ("beyond a reasonable doubt," for example). Applying epistemic understandings of this sort to the operation of collective institutions like courts and juries is notoriously difficult. The standard question is how an individual judge can have the required degree of certainty when others (dissenting judges, a minority of jurors, the majority in the legislature) not only do not have that degree of certainty but actually draw the contrary conclusion from their evaluation of the relevant material? The Supreme Court's decisions on the permissibility of nonunanimous jury verdicts, and on the requirement that juries be unanimous in finding aggravating circumstances in death penalty cases, illustrate the difficulties. See Schad v. Arizona, 501 U.S. 624 (1991) (upholding a capital conviction based on instructions that did not require jurors to agree unanimously on the defendant's state of mind); Apodaca v. Oregon, 406 U.S. 404 (1972) (upholding state laws allowing nonunanimous verdicts in criminal cases).

71. A cousin of Thayerian review can be found in the Supreme Court's doctrine dealing with the circumstances under which a federal court can enjoin a pending prosecution under an unconstitutional statute. The Court has limited those circumstances quite severely, but it has at least held open the possibility that an injunction would be proper against a prosecution for violating a statute that was " flagrantly and patently violative of express constitutional prohibitions in every clause, sentence and paragraph, and in whatever manner and against whomever an effort might be made to apply it.' "Younger v. Harris, 401 U.S. 37, 53-54 (1971) (quoting Watson v. Buck, 313 U.S. 387, 402 (1941)). 
board. Treating Thayerian review as part of an allocation strategy, whereby some constitutional principles receive strong-form review and others Thayerian review, requires the courts to distinguish among constitutional provisions. As we have seen in connection with provisional review, drawing such distinctions in turn requires the courts to place constitutional provisions on a continuum, some being more important - in some sense - than others. Yet, all constitutional provisions have received the same degree of endorsement by the constitution's makers, and the grounds for judicial distinctions among the provisions are quite unclear. The most sustained discussion of which I am aware of distinctions among constitutional rights in Supreme Court opinions is Justice White's assertion in Bowers v. Hardwick, ${ }^{72}$ that the "Court ... comes nearest to illegitimacy when it deals with judge-made constitutional law having little or no cognizable roots in the language or design of the Constitution." Yet, this assertion seems in serious tension with the Ninth Amendment. ${ }^{73}$ Similarly, the assertion in Murdock v. Pennsylvania ${ }^{74}$ that First Amendment rights had a "preferred position," never received an extended defense.

Second, as Justice Souter's formulation suggests, Thayerian review requires the creation of another continuum. Ordinarily, we think of constitutionality as a binary phenomenon: While it may sometimes be hard to figure out whether a statute crosses the line from constitutional permissibility into constitutional violation, we are confident that there is such a line. In Thayerian review, constitutionality is a matter of degree: Unconstitutional, but not too unconstitutional; an error, but not a clear error. The U.S. experience does not give me confidence that judges can figure out ways to develop a continuumized notion of constitutionality. ${ }^{75}$

Third, I suspect that true Thayerian review places judges in a difficult psychological position. The state of mind needed for merely deferential review is easy to achieve. All the judge needs to say is, "I would not vote for this were I a legislator, because I believe it is unwise policy, but - even as a legislator - I wouldn't think that the proposal is unconstitutional." The state of mind of a Thayerian judge is, I suspect, harder to achieve. The Thayerian judge must say, "In my judgment this statute is unconstitutional, but - despite that, and

72. 478 U.S. 186,194 (1986).

73. U.S. CONST. amend. IX ("The enumeration in the Constitution, of certain rights, shall not be construed to deny or disparage others retained by the people.").

74. 319 U.S. 105,115 (1943).

75. My guess, but it is only that, is that strong-form review conduces to making continuumization difficult: A lot of the time the courts will be invoking the constitution understood in binary terms (because such terms make it easier to explain to legislatures and to the people why their choices cannot go into effect in the short run), thereby depriving the courts of many opportunities to design the continuum of unconstitutionality. 
despite the fact that I have the power to block the statute's enforcement - I think that this statute should go into effect because it is not too unconstitutional." Judges accustomed to acting on their judgments of constitutionality may find it hard to refrain from doing so on some occasions. $^{76}$

A fourth reason for skepticism about the possibility of Thayerian review as an allocation strategy for judges is related to the third. A judge, given the choice between exercising strong-form review and exercising Thayerian review, might wonder what could be accomplished by doing the latter. ${ }^{77}$ I have suggested elsewhere that the Thayerian judge might think of his or her choice as tutelary: The judge might instruct legislators on their constitutional obligations by telling them that the statute they have enacted is unconstitutional and that they have to live with that unconstitutionality. ${ }^{78}$ The state of mind of the Thayerian judge might be that of a wise parent, willing to let his or her children make decisions that the parent believes to be unsound so that the children will learn from experience how to make sound ones. ${ }^{79}$

The difficulty with the tutelary view is obvious. Why should legislators who believe that the statute they enacted accomplishes valuable public purposes care that judges think that the legislature's action violates constitutional norms? Sometimes, perhaps, the legislators will have overlooked the constitutional problems the Thayerian court identifies. Having those difficulties pointed out, the legislature might reassess the overall wisdom of the statute, deducting the constitutional costs the court identified from the social benefits the legislature initially identified and, perhaps, concluding that, net, the statute does not actually advance the public well-being. And, sometimes, perhaps, an aroused citizenry will become upset that their representatives have been faithful to the constituents' immediate desires, or perhaps faithful only to the legislators' immediate self-interest, ${ }^{80}$ but unfaithful to

76. I have a similar suspicion about the epistemic version of Thayerian review. That version will sometimes require judges to say to themselves, "I am convinced beyond a reasonable doubt that this statute is unconstitutional even though four of my colleagues, whose judgment is not always unreasonable, believe quite to the contrary, that the statute is entirely constitutional."

77. It is clear enough what is accomplished by exercising strong-form review: An unconstitutional statute is not enforced.

78. Mark Tushnet, Thayer's Target: Judicial Review or Democracy?, 88 Nw. U. L. REv. 9 (1993). There I argue that Thayer himself viewed Thayerian review as tutelary. I should note that even at the time this article was published I was not convinced by my own argument, although I thought then and still do that there were tutelary themes in Thayer's article. For present purposes, though, Thayer's own understanding is unimportant, as I am concerned here with problems Thayerian review poses for judges.

79. I note that in my experience parents have difficulty in achieving this state of mind.

80. On the assumption that the legislators' actions might not correspond to the constituents' immediate preferences because of agency problems. 
the constituents' longer-term commitments as expressed in the constitution.

More likely, though, neither legislators nor constituents will think it necessary to respond to the Thayerian court's decision. The reason is that statutes often express a considered judgment by the legislature that the statutes are consistent with the constitution, and that such a judgment is (often) reasonable even if the judges disagree ${ }^{81}$ Here we can return to Marbury itself. As is well-known, Marshall's opinion uses a rhetorical trick to explain his justification of judicial review. He asks readers to imagine a statute enacted by Congress that makes testimony by one witness sufficient to convict for treason, blatantly contradicting the constitutional requirement of two witnesses. ${ }^{82}$ In such a case Congress could not reasonably have thought that its action was consistent with the Constitution. But, consider the statute at issue in Marbury itself, which the Court held unconstitutional because it altered the allocation of jurisdiction prescribed in the Constitution. It is a standard point in the Marbury literature to note that the Constitution could reasonably be interpreted to allow Congress to shift cases from the constitutionally identified category of appellate jurisdiction to the Supreme Court's original jurisdiction ${ }^{83}$ Most realworld cases are more likely to resemble Marbury than to resemble the hypothetical treason statute. And, in such cases, judges exercising Thayerian tutelary review will confront a legislature whose members can reasonably say to themselves, "We understand that the court's interpretation of the constitution is reasonable, and different from ours, but we also understand that our interpretation is a reasonable one too. Given the choice between two reasonable interpretations, we will adhere to our initial judgment." In short, a Thayerian court may hope to teach the legislature a lesson about the legislature's constitutional obligations, but the students are likely to think the lesson unnecessary.

These problems with true Thayerian review suggest that courts will have difficulty pursuing a defensible strategy in which they allocate some issues to strong-form review and others to Thayerian review.

\section{CONCLUSION}

In asserting that judicial review was necessary to ensure that "the legislature may [not] alter the constitution by an ordinary act, ${ }^{, 84}$ Chief

81. For a more extended discussion, see Mark Tushnet, Non-Judicial Review, 40 HARV. J. ON LEGIS. 453 (2003).

82. Marbury v. Madison, 5 U.S. (1 Cranch) 137, 179 (1803).

83. See, e.g., William Van Alstyne, A Critical Guide to Marbury v. Madison, 1969 DUKE L.J. 1, 31-32.

84. 5 U.S. (1 Cranch) at 177. 
Justice Marshall may be taken to assert as well that constitutionalism requires strong-form judicial review. Weak-form review suggests that there is a category lying between ordinary legislation and extraordinary constitutional amendment. ${ }^{85}$ With the possibility of weak-form review on the table, it becomes possible to consider as well strategies that would allocate some issues to strong-form review, others to weak-form review.

Here I have explored some aspects of allocation strategies operating one level removed from that of constitutional design. I have suggested that allocation strategies may be unstable: A legislative allocation that appears to give courts the power to engage in strong-form review may be revoked, and judicial allocations that appear to commit the courts to weak-form review may, in practical political terms, amount to strong-form review in disguise. More generally, allocation strategies may be designed, consciously or otherwise, to conceal the reality of judicial review - in the one case, to pretend that courts really do have the power to resolve contentious issues permanently, in the other to pretend that the courts are permitting the people to be truly self-governing in the areas subject to weak-form review. Weak-form judicial review, and the possibilities of allocation strategies it creates, are intriguing novelties in constitutional design. It remains to be seen, though, how permanent, enduring, and distinctive their contribution to constitutional design is.

85. Of course, constitutionalist systems lacking judicial review - such as Great Britain's, at least before the adoption of the Human Rights Act 1998 - show that Marshall's claim that constitutionalism requires judicial review is false. What he missed about such systems was the possibility that embedded political norms would place impediments in the way of changing the constitution at least as severe as those created by cumbersome, formal amendment procedures. 